Lingua Rima: Jurnal Pendidikan Bahasa dan Sastra Indonesia

Vol. 10 No. 2 Juli 2021

http://jurnal.umt.ac.id/index.php/lgrm

\title{
PENGARUH METODE KARYAWISATA TERHADAP KEMAMPUAN MENULIS TEKS LAPORAN HASIL OBSERVASI SISWA KELAS VII SMPN 2 MEKARBARU KABUPATEN TANGERANG
}

\author{
Haerudin ${ }^{1}$ \\ Universitas Muhammadiyah Tangerang \\ haeromli@gmail.com \\ Soleh Ibrahim ${ }^{2}$ \\ Universitas Muhammadiyah Tangerang \\ ibrahimasman87@gmail.com
}

\begin{abstract}
ABSTRAK
Penelitian ini bertujuan untuk untuk mengetahui pengaruh metode karyawisata terhadap keterampilan menulis teks hasil laporan observasi siswa kelas VII SMPN 2 Mekarbaru Kabupaten Tangerang. Metode yang digunakan dalam penelitian ini adalah metode Quasi Experimental Design dengan melakukan pretes dan postes pada dua kelompok. Desain penelitian ini menggunakan Nonequivalent Control Group Design. Nonequivalent Control Group Design Data yang diperoleh dari hasil pengisian tes dideskripsikan dengan menggunakan instrumen-instrumen yang dikembangkan. Selanjutnya, data disajikan dalam bentuk tabel distribusi frekuensi, histogram, ogive, poligon. Hasil penelitian pretes dengan uji hipotesis menunjukan hasil $t_{\text {hitung }}(0,21)<t_{\text {tabel }}(1,66)$ ini menunjukkan bahwa tidak terdapat perbedaan yang signifikan terhadap kemampuan menulis teks prosedur antara kelas eksperimen dan kelas kontrol. Analisis postes dengan uji hipotesis menunjukan hasil $t_{\text {hitung }}(6,73)>t_{\text {tabel }}(1,66)$ ini menunjukkan bahwa perbedaan terlihat signifikan terhadap kemampuan menulis teks prosedur sangat berpengaruh pada kemampuan menulis siswa.
\end{abstract}

Kata Kunci: laporan hasil observasi, metode karyawisata

\section{A. PENDAHULUAN}

Siswa dituntut dapat menuangkan ide atau gagasannya. Siswa dituntut untuk lebih aktif dan kreatif dalam mencari informasi dan dapat menuangkannya ke dalam tulisan (Mujianto, Ridhani, dan Arifin, 2017:355). Oleh karena itu, siswa harus dapat memiliki kompetensi dalam keterampilan menulis. Kompetensi dasar menulis tersebut mengisyaratkan sebuah proses. Melalui tahapan proses menulis, menulis merupakan proses kreatif yang banyak melibatkan cara berpikir divergen (menyebar) daripada konvergen (memusat) (Afandi dan Zulaeha, 2017:188). Salah satunya metode yang dapat meningkatkan kemampuan menulis siswa adalah melalui metode karyawisata.

Metode karyawisata bertujuan untuk memperoleh pengalaman langsung dari objek yang dilihatnya, metode karyawisata ini merupakan cara mengajar yang dilaksanakan dengan mengajak siswa ke suatu tampat atau objek tertentu di luar kelas untuk mempelajari suatu Pengaruh Metode Karyawisata terhadap Kemampuan Menulis Teks Laporan Hasil Observasi Siswa Kelas VII SMPN 2 Mekarbaru Kabupaten Tangerang 


\section{Lingua Rima: Jurnal Pendidikan Bahasa dan Sastra Indonesia \\ Vol. 10 No. 2 Juli 2021 \\ http://jurnal.umt.ac.id/index.php/lgrm}

objek sacara langsung dan mendapatkan gambaran secara konkret mengenai hal-hal yang akan ditulis. Melalui metode karyawisata ini, siswa mendapat gambaran konkret mengenai hal-hal yang akan ditulis dengan melihat ataupun merasakan secara langsung objek yang dilihatnya. Pembelajaran menulis teks laporan hasil observasi menerapkan metode karyawisata akan membuat siswa termotivasi untuk mengembangkan kreativitasnya secara optimal.

Hal ini berbeda dengan pembelajaran di dalam kelas, guru menjelaskan terlebih dahulu mengenai teks laporan hasil observasi itu apa, kemudian memberikan contoh mengenai teks laporan hasil observasi, setelah itu siswa mencoba untuk membuat teks laporan hasil observasi sendiri. Tetapi kenyataan dilapangan, kurangnya keaktifan siswa dan kemampuan daya imajinasinya kurang optimal. Hal ini menjadi dampak buruk bagi siswa untuk mendeskripsikan melalui sebuah tulisan. Siswa banyak yang tidak senang apabila diminta untuk membuat suatu karya, siswa menganggap pelajaran menulis sebagai pelajaran yang membosankan dan melelahkan, pembelajaran menulis kadang hanya digunakan sebagai pengisi waktu luang dan tidak memperoleh porsi waktu yang cukup. Hal ini menarik perhatian untuk diteliti upaya yang harus ditempuh untuk menarik perhatian siswa dalam pembelajaran menulis, terutama dalam menulis teks laporan hasil observasi.

Teks laporan hasil observasi merupakan jenis teks yang melaporkan atau menyampaikan hasil suatu pengamatan secara umum. Teks laporan hasil observasi memaparkan hasil pengamatan secara sistematik dan objektif berdasarkan kenyataan atau fakta yang ada (Putri dan R., 2019:64) Objek yang diamati objek disekitar lingkungan sekolah seperi perpustakaan, unit kesehatan sekolah, kegiatan ekstrakulikuler, alam sekitar dan lain sebagainya. Berdasarkan materi pembelajaran menulis teks laporan hasil observasi di SMPN 2 Mekarbaru Kabupaten Tangerang ini masih kurang. Hal ini diketahui hasil observasi SMPN 2 Mekarbaru Kabupaten Tangerang dengan mewawancarai guru mata pelajaran bahasa Indonesia kelas VII menyatakan bahwa kemampuan menulis teks laporan hasil observasi masih di bawah Kriteria Ketuntasan Minimal (KKM) yang ditentukan oleh SMPN 2 Mekarbaru Kabupaten Tangerang dengan nilai 70.

Hal ini disebabkan adanya faktor dalam pembelajaran masih menggunakan model konvensional, pembelajaran yang hanya terpusat pada guru. Sehingga, siswa tersebut menjadi kurang aktif saat pembelajaran berlangsung. Selain itu kurangnya minat belajar siswa terhadap kemampuan menulis teks laporan hasil observasi SMPN 2 Mekarbaru Kabupaten 


\section{Lingua Rima: Jurnal Pendidikan Bahasa dan Sastra Indonesia \\ Vol. 10 No. 2 Juli 2021 \\ http://jurnal.umt.ac.id/index.php/lgrm}

Tangerang, metode yang digunakan kurang tepat dan materi pembelajaran menulis teks laporan hasil observasi yang sulit. Agar minat siswa dalam hal menulis khususnya menulis teks laporan hasil observasi menjadi termotivasi perlu adanya motode pembelajaran yang dapat merangsang daya pikir siswa. Metode karyawisata ini mempunyai kemampuan yang lebih baik karena, dapat membuat siswa termotivasi untuk mengembangkan kreativitasnya secara optimal dalam menuangkan ide atau gagasannya dengan melihat objeknya secara langsung dan proses kegiatan yang dilakukan di luar kelas, sehingga metode ini dapat membantu guru dalam proses belajar mengajar pada siswa.

Penelitian terdahulu dilakukan oleh Sari, Syahrul, dan Rasyid (2018) dengan judul Hubungan Antara Keterampilan Membaca Pemahaman dengan Keterampilan Menulis Teks Laporan Hasil Observasi Siswa Kelas X SMK Negeri 3 Padang menghasilkan keterampilan membaca pemahaman teks Laporan Hasil Observasi observasi sebesar 0,788\% dengan keterampilan menulis teks Laporan Hasil Observasi siswa kelas X SMK Negeri 3 Padang dan selebihnya dipengaruhi oleh faktor lain yang tidak diteliti dalam penelitian ini. Selain itu, penelitian oleh Yulia (2017) dengan judul Peningkatan Keterampilan Menulis Teks Laporan Hasil Observasi dengan Menggunakan Metode Field Trip menghasilkan terjadi peningkatan keterampilan siswa menulis teks hasil observasi setelah mengikuti pembelajaran dengan menggunakan metode field trip dari siklus 1 ke siklus 2. Hal tersebut dibuktikan nilai keseluruhan siswa kelas X Akuntansi 2 SMK Negeri 1 Rancah pada siklus 1 mencapai ratarata nilai 74,5 selanjutnya pada siklus 2 mencapai rata-rata nilai 84,4.

\section{B. METODE PENELITIAN}

Metode yang digunakan dalam penelitian ini adalah metode Quasi Experimental Design dengan melakukan pretes dan postes pada dua kelompok. Jenis metode penelitian eksperimen ini menggunakan desain penelitian Nonequivalent Control Group Design. Dimana kelas eksperimen desain diberi perlakuan dan kelas kontrol tidak diberi perlakuan. Nonequivalent Control Group Design ini hampir sama dengan pretes dan postest kontrol group desain, hanya pada desain ini kelompok eksperimen maupun kontrol tidak dipilih secara random. Desain rancangan penelitian Nonequivalent Control Design menurut Riadi (2014:14) dapat dilihat melalui tabel di bawah ini.

\section{Tabel 3.1 Desain Penelitian}

\begin{tabular}{|c|c|c|c|}
\hline Kelompok & Pretest & Perlakuan & Postest \\
\hline Eksperimental & $\mathrm{Y}_{\mathrm{e}}$ & $\mathrm{X}$ & $\mathrm{Y}_{\mathrm{e}}$ \\
\hline Kontrol & $\mathrm{Y}_{\mathrm{k}}$ & - & $\mathrm{Y}_{\mathrm{k}}$ \\
\hline
\end{tabular}

Pengaruh Metode Karyawisata terhadap Kemampuan Menulis Teks Laporan Hasil Observasi Siswa Kelas VII SMPN 2 Mekarbaru Kabupaten Tangerang 


\section{Lingua Rima: Jurnal Pendidikan Bahasa dan Sastra Indonesia \\ Vol. 10 No. 2 Juli 2021 \\ http://jurnal.umt.ac.id/index.php/lgrm}

Keterangan :

$\mathrm{Y}_{\mathrm{e}} \quad=$ Data hasil pretes / postes kelas eksperimen

$\mathrm{Y}_{\mathrm{k}} \quad=$ Data hasil pretes / postes kelas kontrol

$\mathrm{X}=$ Perlakuan yang di eksperimenkan

Populasi dalam penelitian ini adalah siswa kelas VII MTS. Daarul Muqimien Kabupaten Tangerang yang terdaftar pada tahun ajaran 2019/2020 yang berjumlah 88 siswa. Sampel dalam penelitian ini, sampel diambil dengan cara memilih 2 kelas dari 3 kelas, dimana 1 kelas akan dijadikan kelas kontrol dan kelas 1 lagi dijadikan kelas eksperimen. Yang dijadikan sampel dalam penelitian ini adalah kelas VII B sebagai kelas eksperimen, yaitu kelas yang menggunakan metode karyawisata dan kelas VII C sebagai kelas kontrol, yaitu kelas yang tidak menggunakan metode karyawisata.

Peneliti menggunakan teknik tes dalam bentuk tes uraian (esai), karena esai adalah suatu bentuk pertanyaan yang menuntut jawaban siswa dalam bentuk uraian dengan mempergunakan bahasa sendiri. Observasi dilakukan pada hari Selasa, 28 Januari 2020. Halhal yang di observasi adalah proses pembelajaran di kelas VII B dan VII C. Wawancara dilakukan pada hari Selasa, 28 Januari 2020, dalam hal ini yang menjadi narasumber adalah guru mata pelajara bahasa Indonesia kelas VII MTs. Daarul Muqimien Kabupaten Tangerang. Teknik analisis data dalam penelitian ini menggunakan penggabungan nilai pretest dan postest. Uji prasyarat data menggunakan uji normalitas sebaran data mengunakan chi-khuadrat, uji homogenitas varian dengan uji-F, uji hipotesis dengan menggunakan uji beda mean (uji-t) Polled varian.

\section{HASIL PENELITIAN DAN PEMBAHASAN}

Penelitain ini dilakukan di SMPN 2 Mekarbaru Tangerang dengan alamat Jalan K.H. Suhaemi No. 3 Desa Mekarbaru Kec. Mekarbaru Kabupaten Tangerang. Penelitian ini menggunakan dua kelas sebagai sampel, yaitu kelas VII-2 sebagai kelas kontrol yang tidak mendapatkan pembelajaran metode karyawisata dan kelas VII-3 sebagai kelas eksperimen yang mendapatkan pembelajaran menggunakan metode karyawisata. Penelitian ini dilakukan selama empat kali pertemuan pada tiap kelas kontrol dan kelas eksperimen, yang terdiri dari dua tes yaitu pretes dan postes, dengan dua kali pemberian materi. Materi Bahasa Indonesia yang diajarkan yaitu keterampilan menulis teks laporan hasil observasi. Dengan demikian, sebelum diberikan perlakuan, kedua kelompok tersebut diberikan tes pretes. Tes tersebut diberikan untuk mengetahui tingkat kesetaraan kedua kelompok tersebut dalam materi 
Lingua Rima: Jurnal Pendidikan Bahasa dan Sastra Indonesia

Vol. 10 No. 2 Juli 2021

http://jurnal.umt.ac.id/index.php/lgrm

menulis teks laporan hasil observasi. Setelah itu, diberikan perlakuan kemudian kelompok tersebut diberikan postes untuk mengetahui apakah terdapat pengaruh keterampilan menulis teks laporan hasil observasi dari kedua kelompok tersebut.

Data dalam penelitian ini diperoleh dari pretes dan postes dapat memberikan gambaran mengenai keterampilan menulis teks laporan hasil observasi siswa terhadap penggunaan metode karyawisata. Data yang dideskripsikan adalah data yang diperoleh dari hasil pengisian tes dengan menggunakan instrumen-instrumen yang dikembangkan. Selanjutnya, data disajikan ke dalam bentuk tabel distribusi frekuensi, histogram, ogive, poligon.

a. Pretes Kelas Kontrol

1) Penyajian Data Penelitian

Data akan disajikan dalam bentuk tabel distribusi frekuensi, histrogram, poligon dan ogive

Tabel 4.1 Distribusi Frekuensi Pretes Kelas Kontrol

\begin{tabular}{|c|c|c|}
\hline Kelas & Interval & Frekuensi \\
\hline 1 & $25-31$ & 4 \\
\hline 2 & $32-38$ & 3 \\
\hline 3 & $39-45$ & 6 \\
\hline 4 & $46-52$ & 5 \\
\hline 5 & $53-59$ & 7 \\
\hline 6 & $60-66$ & 5 \\
\hline 7 & $67-73$ & 2 \\
\hline Jumlah & & 32 \\
\hline
\end{tabular}

2) Mencari Pemusatan Data

\begin{tabular}{|c|c|c|c|c|c|}
\hline Kelas & \multicolumn{2}{|c|}{ Interval } & $\mathrm{Xi}$ & $\mathrm{Fi}$ & fi.xi \\
\hline 1 & 25 & 31 & 28 & 4 & 112 \\
\hline 2 & 32 & 38 & 35 & 3 & 105 \\
\hline 3 & 39 & 45 & 42 & 6 & 252 \\
\hline 4 & 46 & 52 & 49 & 5 & 245 \\
\hline 5 & 53 & 59 & 56 & 7 & 392 \\
\hline 6 & 60 & 66 & 63 & 5 & 315 \\
\hline 7 & 67 & 73 & 70 & 2 & 140 \\
\hline Jumlah & & & & 32 & 1561 \\
\hline
\end{tabular}

Pengaruh Metode Karyawisata terhadap Kemampuan Menulis Teks Laporan Hasil Observasi Siswa Kelas VII SMPN 2 Mekarbaru Kabupaten Tangerang 
Lingua Rima: Jurnal Pendidikan Bahasa dan Sastra Indonesia

Vol. 10 No. 2 Juli 2021

http://jurnal.umt.ac.id/index.php/lgrm

1) Mean

$$
\begin{aligned}
& =\frac{1561}{32} \\
& =48,78
\end{aligned}
$$

2) Median

$$
\begin{aligned}
\mathrm{Me} & =\mathrm{L} o+\mathrm{I} \\
& =45,5+7 \\
& =49,7
\end{aligned}
$$

\begin{tabular}{|c|c|c|c|c|c|c|c|}
\hline \multicolumn{2}{|c|}{ Interval } & $\mathrm{Fi}$ & $\mathrm{xi}$ & fi.xi & $x^{-}$ & $\left(x i-x^{-}\right) 2$ & fi. $\left(x i-x^{-}\right) 2$ \\
\hline 25 & 31 & 4 & 28 & 112 & \multirow{8}{*}{48,78125} & 431,8604 & 1727,4414 \\
\hline 32 & 38 & 3 & 35 & 105 & & 189,9229 & 569,76855 \\
\hline 39 & 45 & 6 & 42 & 252 & & 45,98535 & 275,91211 \\
\hline 46 & 52 & 5 & 49 & 245 & & 0,047852 & 0,2392578 \\
\hline 53 & 59 & 7 & 56 & 392 & & 52,11035 & 364,77246 \\
\hline 60 & 66 & 5 & 63 & 315 & & 202,1729 & 1010,8643 \\
\hline 67 & 73 & 2 & 70 & 140 & & 450,2354 & 900,4707 \\
\hline$\sum$ & & 32 & & 1561 & & & 4849,4688 \\
\hline
\end{tabular}

3) Modus

$$
\begin{aligned}
\text { Mo } & =\operatorname{Lo}+\mathrm{I}() \\
& =52,5+7()
\end{aligned}
$$

3) Mencari Penyebaran Data

1) Simpangan Baku Data Berkelompok

$$
\begin{aligned}
S & =2^{2} \\
& \mathrm{n}-1 \\
= & 31 \\
= & 12,26
\end{aligned}
$$

2) Varians

Varians (Ragam) adalah kuadrat dari simpangan baku

$$
S^{2}=(12,26)^{2}
$$

Pengaruh Metode Karyawisata terhadap Kemampuan Menulis Teks Laporan Hasil Observasi Siswa Kelas VII SMPN 2 Mekarbaru Kabupaten Tangerang 


\section{Lingua Rima: Jurnal Pendidikan Bahasa dan Sastra Indonesia \\ Vol. 10 No. 2 Juli 2021 \\ http://jurnal.umt.ac.id/index.php/lgrm \\ $=150,31$}

\section{b. Pengujian Persyaratan Analisis Data}

Uji persyaratan analisis data penelitian dilakukan dengn menggunakan uji normalitas dan uji homogenitas. Uji normalitas yaitu uji yang dilakukan untuk mengetahui data memiliki sebaran normal atau tidak, sedangkan uji homogenitas yaitu uji yang dilakukan untuk mengetahui data homogen atau tidak dari masing-masing kelompok data

1. Uji Normalitas

Uji normalitas dalam penelitian ini, peneliti menggunakan rumus Chi Kuadrat yang dilakukan dari data kontrol dan data eksperimen untuk menguji normalitas kedua data tersebut distribusi normal atau tidak distribusi normal. Kriteria pengujian dinyatakan berdistribusi normal jika $x^{2}$ hitung $<x^{2}$ tabel sebaliknya jika $x^{2}$ hitung $>x^{2}$ tabel maka data berdistribusi tidak normal.

a. Uji Normalitas Pretes Kelas Kontrol

\begin{tabular}{|c|c|c|c|c|c|c|c|c|}
\hline kelas & Interval & fi & tepi kelas $(\mathrm{x})$ & $\mathrm{Z}$ & $\mathrm{F}(\mathrm{z})$ & selisih luas & fe & (fi-fe)^2/fe $^{\wedge}$ \\
\hline 1 & $25-31$ & 4 & 24,5 & $-1,97$ & 0,0244 & 0,0564 & 1,80 & 2,67 \\
\hline 2 & $32-38$ & 3 & 31,5 & $-1,4$ & 0,0808 & 0,1225 & 3,92 & 0,21 \\
\hline 3 & $39-45$ & 6 & 38,5 & $-0,83$ & 0,2033 & 0,1941 & 6,21 & 0,00 \\
\hline 4 & $46-52$ & 5 & 45,5 & $-0,26$ & 0,3974 & 0,2205 & 7,05 & 0,59 \\
\hline 5 & $53-59$ & 7 & 52,5 & 0,3 & 0,6179 & 0,1899 & 6,07 & 0,14 \\
\hline 6 & $60-66$ & 5 & 59,5 & 0,87 & 0,8078 & 0,1137 & 3,63 & 0,50 \\
\hline 7 & $67-73$ & 2 & 66,5 & 1,44 & 0,9251 & 0,0527 & 1,68 & 0,05 \\
\hline & & & 73,5 & 2,01 & 0,9778 & & & \\
\hline Jumlah & & 32 & & & & & & 4,20 \\
\hline
\end{tabular}

Berdasarkan nilai pretes kelas kontrol yang diperoleh peneliti $\mathrm{X}_{\text {hitung }}^{2}=4,20$ dan $\mathrm{X}_{\text {tabel }}^{2}=12,592$ pada taraf signifikan $\alpha=5 \%$ atau 0,05 dengan jumlah $n=32$, Jika $\mathrm{X}_{\text {hitung }}^{2}=4,20<\mathrm{X}_{\text {tabel }}^{2}=12,592$ dapat disimpulkan bahwa data pretes kelas kontrol berdistribusikan normal.

\begin{tabular}{|c|c|c|c|c|c|c|c|c|}
\hline Kelas & Interval & $\mathrm{fi}$ & tepi kelas $(\mathrm{x})$ & $\mathrm{Z}$ & $\mathrm{F}(\mathrm{z})$ & selisih luas & $\mathrm{fe}$ & $(\mathrm{fi}-\mathrm{fe})^{\wedge} 2 / \mathrm{fe}$ \\
\hline 1 & $25-31$ & 4 & 24,5 & $-1,76$ & 0,0392 & 0,0683 & 2,18 & 1,50 \\
\hline 2 & $32-38$ & 5 & 31,5 & $-1,24$ & 0,1075 & 0,1314 & 4,20 & 0,15 \\
\hline
\end{tabular}

Pengaruh Metode Karyawisata terhadap Kemampuan Menulis Teks Laporan Hasil Observasi Siswa Kelas VII SMPN 2 Mekarbaru Kabupaten Tangerang 
Lingua Rima: Jurnal Pendidikan Bahasa dan Sastra Indonesia

Vol. 10 No. 2 Juli 2021

http://jurnal.umt.ac.id/index.php/lgrm

\begin{tabular}{|c|c|c|c|c|c|c|c|c|}
3 & $39-45$ & 7 & 38,5 & $-0,71$ & 0,2389 & 0,1858 & 5,94 & 0,18 \\
\hline 4 & $46-52$ & 3 & 45,5 & $-0,19$ & 0,4247 & 0,2008 & 6,42 & 1,82 \\
\hline 5 & $53-59$ & 4 & 52,5 & 0,32 & 0,6255 & 0,1768 & 5,65 & 0,48 \\
\hline 6 & $60-66$ & 6 & 59,5 & 0,85 & 0,8023 & 0,1124 & 3,59 & 1,60 \\
\hline 7 & $67-73$ & 3 & 66,5 & 1,37 & 0,9147 & 0,0559 & 1,78 & 0,82 \\
\hline & & & 73,5 & 1,89 & 0,9706 & & & \\
\hline Jumlah & & 32 & & & & & & 6,58 \\
\hline
\end{tabular}

b. Uji Normalitas Pretes Kelas Eksperimen

Berdasarkan nilai pretes kelas eksperimen yang diperoleh peneliti $\mathrm{X}_{\text {hitung }}=6,58$, dan $\mathrm{X}_{\text {tabel }}^{2}=12,592$ pada taraf signifikan $\alpha=5 \%$ atau 0,05 dengan jumlah $n=32$, Jika $\mathrm{X}_{\text {hitung }}^{2} 6,58<\mathrm{X}_{\text {tabel }}^{2}=12,592$ dapat disimpulkan bahwa data pretes kelas eksperimen berdistribusikan normal

c. Uji Normalitas Postes Kelas Kontrol

\begin{tabular}{|c|c|c|c|c|c|c|c|c|}
\hline Kelas & $\begin{array}{c}\text { Interva } \\
1\end{array}$ & $\mathrm{fi}$ & $\begin{array}{c}\text { tepi kelas } \\
(\mathrm{x})\end{array}$ & $\mathrm{Z}$ & $\mathrm{F}(\mathrm{z})$ & selisih luas & $\mathrm{fe}$ & $\begin{array}{c}\text { (fi- } \\
\text { fe) })^{\wedge} / \mathrm{fe}\end{array}$ \\
\hline 1 & $35-40$ & 3 & 34,5 & $-2,28$ & 0,0113 & 0,0333 & 1,06 & 3,51 \\
\hline 2 & $41-46$ & 2 & 40,5 & $-1,7$ & 0,0446 & 0,0868 & 2,77 & 0,21 \\
\hline 3 & $47-52$ & 4 & 46,5 & $-1,12$ & 0,1314 & 0,1632 & 5,22 & 0,28 \\
\hline 4 & $53-58$ & 5 & 52,5 & $-0,54$ & 0,2946 & 0,2174 & 6,95 & 0,55 \\
\hline 5 & $59-64$ & 8 & 58,5 & 0,03 & 0,512 & 0,2171 & 6,94 & 0,15 \\
\hline 6 & $65-70$ & 7 & 64,5 & 0,61 & 0,7291 & 0,1539 & 4,92 & 0,87 \\
\hline 7 & 7176 & 3 & 70,5 & 1,19 & 0,883 & 0,0786 & 2,51 & 0,09 \\
\hline & & & 76,5 & 1,77 & 0,9616 & & & \\
\hline & & 32 & & & & & & 5,69 \\
\hline
\end{tabular}

Berdasarkan nilai postes kelas kontrol yang diperoleh peneliti $\mathrm{X}^{2}$ hitung $=5,69$ dan $\mathrm{X}_{\text {tabel }}^{2}=12,592$ pada taraf signifikan $\alpha=5 \%$ atau 0,05 dengan jumlah $n=32$, Jika $\mathrm{X}_{\text {hitung }}^{2}=5,69<\mathrm{X}_{\text {tabel }}^{2}=12,592$ dapat disimpulkan bahwa data postes kelas kontrol berdistribusikan normal

d. Uji Normalitas Postes Kelas Eksperimen

\begin{tabular}{|c|c|c|c|c|c|c|c|c|}
\hline No & Interval & $\mathrm{fi}$ & $\begin{array}{c}\text { tepi kelas } \\
(\mathrm{x})\end{array}$ & $\mathrm{Z}$ & $\mathrm{F}(\mathrm{z})$ & $\begin{array}{c}\text { Selisih } \\
\text { luas }\end{array}$ & $\mathrm{fe}$ & ${\text { (fi-fe) })^{\wedge} / \mathrm{fe}}$ \\
\hline 1 & $55-60$ & 3 & 54,5 & $-2,08$ & 0,0188 & 0,0635 & 2,03 & 0,46 \\
\hline 2 & $61-66$ & 5 & 60,5 & $-1,39$ & 0,0823 & 0,1628 & 5,20 & 0,00 \\
\hline 3 & $67-72$ & 9 & 66,5 & $-0,69$ & 0,2451 & 0,2549 & 8,15 & 0,08 \\
\hline 4 & $73-78$ & 6 & 72,5 & 0 & 0,5 & 0,2517 & 8,05 & 0,52 \\
\hline 5 & $79-84$ & 6 & 78,5 & 0,68 & 0,7517 & 0,1645 & 5,26 & 0,10 \\
\hline 6 & $85-91$ & 3 & 84,5 & 1,38 & 0,9162 & 0,0695 & 2,22 & 0,27 \\
\hline & & & 91,5 & 2,19 & 0,9857 & & & \\
\hline
\end{tabular}

Pengaruh Metode Karyawisata terhadap Kemampuan Menulis Teks Laporan Hasil Observasi Siswa Kelas VII SMPN 2 Mekarbaru Kabupaten Tangerang 
Lingua Rima: Jurnal Pendidikan Bahasa dan Sastra Indonesia

Vol. 10 No. 2 Juli 2021

http://jurnal.umt.ac.id/index.php/lgrm

32

Berdasarkan nilai postes kelas kontrol yang diperoleh peneliti $\mathrm{X}^{2}{ }_{\text {hitung }}=1,45$ dan

$\mathrm{X}_{\text {tabel }}^{2}=11,07$ pada taraf signifikan $\alpha=5 \%$ atau 0,05 dengan jumlah $n=32$, Jika

$\mathrm{X}_{\text {hitung }}^{2}=1,45<\mathrm{X}_{\text {tabel }}^{2}=11,07$ dapat disimpulkan bahwa data postes kelas kontrol berdistribusikan normal.

2. Uji Homogenitas

Uji Homogenitas dalam penelitian ini yaitu dengan menggunakan uji Fhiser. Uji fhiser adalah persamaan dau variasi antara kelas kontrol dan kelas eksperimen. Uji homogenitas dilakukan untuk mengetahui ada atau tidaknya kesamaan variansi kelas, maka dapat dikatakan bahwa kelompok tersebut berasal dari populasi yang homogen. Kriteria pengujiannya yaitu variansi populasi antara dua kelas yang sama jika $F_{\text {hitung }}>$ $\mathrm{F}_{\text {tabel }}$ maka data tidak homogen. Taraf signifikannya yaitu $\alpha=0,05$ atau 5\%. Adapun hasil perhitungan diperoleh sebagai berikut.

a. Hasil Uji Homogenitas Pretes

Perhitungan persebaran data nilai pretes kelas kontrol dan eksperimen didapat varians terbesar 178,75 dan varians terkecil 150,31 maka:

$\mathrm{F}_{\text {hit }}=1,18$

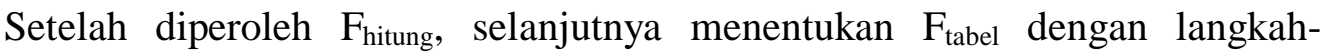
langkah sebagai berikut:

1) Menentukan derajat kebebasan

$$
\text { 2) } \begin{aligned}
\mathrm{Dk}_{1} & =\mathrm{n}_{1}-1=32-1=31 \\
\mathrm{Fk}_{1} & =\mathrm{n}_{2}-1=31-1=31 \\
& =(\alpha ;) \\
& =(0,05 ;) \\
\mathrm{F}_{\text {tabel }} & =1,82
\end{aligned}
$$

Hasil perhitungan pretes diporelh $F_{\text {hitung }}=1,18$ dan $F_{\text {tabel }}=1,82$ sehingga $F_{\text {hitung }}$ $=1,18<\mathrm{F}_{\text {tabel }}=1,82$, sehingga dapat disimpulkan bahwa kedua varian populasi tersebut homogen.

b. Hasil Uji Homogenitas Postes

Perhitungan persebaran data nilai pretes kelas kontrol dan eksperimen didapat varians terbesar yaitu 106,70 dan varians terkecil yaitu 76,64 maka: 
Lingua Rima: Jurnal Pendidikan Bahasa dan Sastra Indonesia

Vol. 10 No. 2 Juli 2021

http://jurnal.umt.ac.id/index.php/lgrm

$\mathrm{F}_{\text {hit }}=1,39$

Setelah diperoleh $F_{\text {hitung, }}$, selanjutnya menentukan $F_{\text {tabel }}$ dengan langkah-langkah sebagai berikut:

1) Menentukan derajat kebebasan

$$
\text { 2) } \begin{aligned}
\mathrm{Dk}_{1} & =\mathrm{n}_{1}-1=32-1=31 \\
\mathrm{Fk}_{1} & =\mathrm{n}_{2}-1=31-1=31 \\
& =(\alpha ;) \\
\mathrm{F}_{\text {tabel }} & =1,82
\end{aligned}
$$

Hasil perhitungan postes diperoleh $\mathrm{F}_{\text {hitung }}=1,39$ dan $\mathrm{F}_{\text {tabel }}=1,82$ sehingga $F_{\text {hitung }}=1,39<$ dan $F_{\text {tabel }}=1,82$, sehingga dapat disimpulkan bahwa kedua varian populasi tersebut homogen.

\begin{tabular}{|c|c|c|c|}
\hline Data & Nilai $F_{\text {hitung }}$ & Nilai $F_{\text {tabel }}$ & Keterangan \\
\hline Pretes & 1,18 & 1,82 & $\begin{array}{c}\text { Data sampel } \\
\text { berasal dari }\end{array}$ \\
\hline Postes & 1,39 & 1,82 & $\begin{array}{c}\text { populasi yang } \\
\text { homogenitas }\end{array}$ \\
\hline
\end{tabular}

Hasil pengujian homogenitas untuk mengetahui keterampilan menulis teks prosedur siswa antara kelas kontrol dan kelas eksperimen dapat dilihat pada tabel di bawah ini:

Tabel 4.2 Hasil Perhitungan Uji Homogenitas

c. Pengujian Hipotesis

Hipotesis yang diuji dalam penelitian ini adalah terdapat pengaruh teknik pemodelan terhadap keterampilan menulis teks prosedur kelas XI SMK Prima Wisata Jakarta. Untuk melihat perbedaan hasil kelompok kontrol dan eksperimen yang diteliti, peneliti menggunakan uji $\mathrm{t}$ dengan rumus the pooled variance model t-test. Kriteria uji hipotesis jika $t_{\text {hitung }}<t_{\text {tabel }}$ maka $\mathrm{H}_{0}$ diterima, dan $\mathrm{t}_{\text {hitung }}>\mathrm{t}_{\text {tabel }}$ maka $\mathrm{H}_{1}$ diterima.

1. Menentukan Nilai Uji t Pretes

$$
\mathrm{t}=0,21
$$


Lingua Rima: Jurnal Pendidikan Bahasa dan Sastra Indonesia

Vol. 10 No. 2 Juli 2021

http://jurnal.umt.ac.id/index.php/lgrm

Menentukan derajat kebebasan $(\mathrm{db})=\mathrm{n}_{1}+\mathrm{n}_{2}-2$

$\mathrm{Db}=32+32-2=62$

Menentukan nilai $t_{\text {tabel }}$

Pada taraf signifikasi $5 \%$ atau 0,05

$\mathrm{t}_{\text {tabel }}(0,05 ; 62)=1,66$

berdasarkan hasil analisis pretes yang menggunakan uji the pooled variance model $t$-test diperoleh data $t_{\text {hitung }}=0,21$ dan $t_{\text {tabel }}=1,66$ pada taraf signifikansi $\alpha=$ 0,05. Hasil perhitungan tersebut diperoleh angka $\mathrm{t}_{\text {hitung }} 0,21<\mathrm{t}_{\text {table }}=1,66$ maka dapat disimpulkan $\mathrm{H}_{0}$ diterima artinya tidak terdapat pengaruh yang signifikan terhadap keterampilan menulis teks prosedur antara siswa yang mendapat pembelajaran menggunakan media PowerPoint dengan siswa yang mendapat media pembelajaran tanpa PowerPoint.

2. Menentukan Nilai Uji t Postes

$\mathrm{t}=6,73$

Menentukan derajat kebebasan $(\mathrm{db})=\mathrm{n}_{1}+\mathrm{n}_{2}-2$

$\mathrm{Db}=32+32-2=62$

Menentukan nilai $t_{\text {tabel }}$

Pada taraf signifikasi 5\% atau 0,05

$t_{\text {tabel }}(0,05 ; 62)=1,66$

Berdasarkan hasil analisis postes yang menggunakan uji the pooled variance model $t$-test diperoleh data $\mathrm{t}_{\text {hitung }}=6,73$ dan $\mathrm{t}_{\text {tabel }}=1,66$ pada taraf signifikansi $\alpha=$ 0,05. Hasil perhitungan tersebut diperoleh angka $\mathrm{t}_{\text {hitung }} 6,73>\mathrm{t}_{\text {tabel }}=1,66$ maka dapat disimpulkan $\mathrm{H}_{1}$ diterima artinya terdapat pengaruh yang signifikan terhadap keterampilan menulis teks prosedur antara siswa yang mendapat pembelajaran menggunakan metode karyawisata dengan siswa yang tidak menggunakan metode karyawisata.

\begin{tabular}{|l|l|l|l|}
\hline Data & Nilai $\mathrm{t}_{\text {hitung }}$ & Nilai & Keterangan \\
\hline Pretes & 0,21 & 1,66 & $\begin{array}{l}\mathrm{t}_{\text {hitung }}<\mathrm{t}_{\text {tabel }} \text { tidak terdapat perbedaan } \\
\text { hasil belajar menulis teks prosedur } \\
\text { siswa yang menggunakan media } \\
\text { PowerPoint dengan siswa yang tidak } \\
\text { menggunakan media PowerPoint. }\end{array}$ \\
\hline Postes & 6,73 & 1,66 & $\begin{array}{l}\mathrm{T}_{\text {hitung }}>\mathrm{t}_{\text {tabel }} \text { terdapat perbedaan hasil } \\
\text { belajar menulis teks prosedur siswa } \\
\text { yang menggunakan media }\end{array}$ \\
\hline
\end{tabular}

Pengaruh Metode Karyawisata terhadap Kemampuan Menulis Teks Laporan Hasil Observasi Siswa Kelas VII SMPN 2 Mekarbaru Kabupaten Tangerang 


\begin{tabular}{|l|l|l|}
\hline & & $\begin{array}{l}\text { PowerPoint dengan siswa yang tidak } \\
\text { menggunakan media PowerPoint. }\end{array}$ \\
\hline
\end{tabular}

Berdasarkan hasil pengujian maka dapat disimpulkan bahwa pretes $\mathrm{H}_{0}$ tidak diterima yang menyatakan bahwa tidak terdapat perbedaan yang signifikan terhadap keterampilan menulis teks prosedur antara siswa kelas eksperimen dengan siswa kelas kontrol. Sedangkan postes $\mathrm{H}_{1}$ diterima yang menyatakan bahwa terdapat perbedaan hasil belajar menulis teks prosedur antara siswa yang menggunakan media PowerPoint dengan siswa yang tidak menggunakan media PowerPoint.

Penelitian ini menggunakan metode kuantitatif yaitu dengan menggunakan statistik dari hasil observasi aktivitas untuk mengetahui peningkatan hasil belajar keterampilan menulis teks prosedur kelas XI dengan menggunakan media PowerPoint. Pembahasan hasil penelitian ini untuk menunjukan jawaban semua permasalahan dalam penelitian yaitu untuk mengetahui hasil belajar peserta didik terhadap keterampilan menulis teks prosedur kelas XI dengan menggunakan media PowerPoint.

Berdasarkan hasil analisis pretes dengan uji hipotesis menunjukan hasil $t_{\text {hitung }}(0,21)<$ $t_{\text {tabel }}(1,66)$ ini menunjukkan bahwa tidak terdapat perbedaan yang signifikan terhadap kemampuan menulis teks prosedur antara kelas eksperimen dan kelas kontrol. Analisis postes dengan uji hipotesis menunjukan hasil $t_{\text {hitung }}(6,73)>t_{\text {tabel }}(1,66)$ ini menunjukkan bahwa perbedaan terlihat signifikan terhadap kemampuan menulis teks prosedur sangat berpengaruh pada kemampuan menulis siswa. Berdasarkan hasil analisis postes yang menggunakan uji t the pooled variance model $t$-test diperoleh data $\mathrm{t}_{\text {hitung }}=6,73$ dan $\mathrm{t}_{\text {tabel }}=1,66$ pada taraf signifikansi $\alpha=0,05$. Hasil perhitungan tersebut diperoleh angka $t_{\text {hitung }} 6,73>t_{\text {tabel }}=1,66$ maka dapat disimpulkan $\mathrm{H}_{1}$ diterima artinya terdapat pengaruh yang signifikan terhadap keterampilan menulis teks prosedur antara siswa yang mendapat pembelajaran menggunakan metode karyawisata dengan siswa yang tidak menggunakan metode karyawisata.

Hasil pengujian di atas diperoleh bahwa rata-rata keterampilan menulis teks laporan hasil observasi yang mendapatkan pembelajaran dengan menggunakan metode karyawisata lebih tinggi dibandingkan dengan keterampilan menulis teks laporan hasil observasi yang tidak menggunakan metode karyawisata. Pembelajaran yang menggunakan metode karyawisata di kelas eksperimen, mendapatkan hasil lebih tinggi dari pada kelas kontrol yang tidak menggunakan metode karyawisata. Hal ini dapat dilihat dari media pembelajaran yang diberikan, dalam media pembelajaran ini siswa dilatih untuk berpikir kritis dan lebih aktif 
Lingua Rima: Jurnal Pendidikan Bahasa dan Sastra Indonesia

Vol. 10 No. 2 Juli 2021

http://jurnal.umt.ac.id/index.php/lgrm

dengan teman, guru, bahkan dengan dirinya sendiri untuk mencari tahu akan materi yang diberikan.

Berbeda dengan kelas kontrol yang tidak menggunakan metode karyawisata, selama pembelajaran berlangsung guru hanya menjelaskan materi dan siswa hanya mencatat apa yang telah disampaikan oleh guru ketika guru memerintahkan siswa untuk menulis teks laporan hasil observasi. Dengan demikan, maka hasil penelitian ini menunjukkan bahwa terdapat perbedaan keterampilan menulis teks laporan hasil observasi yang diajarkan dengan menggunakan metode karyawisata dan yang tidak menggunakan metode karyawisata.

\section{KESIMPULAN DAN SARAN}

Hasil penelitian ini menunjukkan bahwa metode karyawisata mempunyai peran penting dalam pembelajaran menulis teks laporan hasil observasi. Hal itu ditunjukkan oleh hasil penelitian ini bahwa metode karya wisata sangat efektif dugunakan dalam mencapai tujuan pembelajaran menulis teks laporan hasil observasi. Berdasarkan hasil analisis pretes dengan uji hipotesis menunjukan hasil $t_{\text {hitung }}(0,21)<t_{\text {tabel }}(1,66)$ ini menunjukkan bahwa tidak terdapat perbedaan yang signifikan terhadap kemampuan menulis teks prosedur antara kelas eksperimen dan kelas kontrol. Analisis postes dengan uji hipotesis menunjukan hasil $t_{\text {hitung }}$ $(6,73)>t_{\text {tabel }}(1,66)$ ini menunjukkan bahwa perbedaan terlihat signifikan terhadap kemampuan menulis teks prosedur sangat berpengaruh pada kemampuan menulis siswa. Berdasarkan hasil analisis postes yang menggunakan uji t the pooled variance model t-test diperoleh data $t_{\text {hitung }}=6,73$ dan $t_{\text {tabel }}=1,66$ pada taraf signifikansi $\alpha=0,05$. Hasil perhitungan tersebut diperoleh angka $\mathrm{t}_{\text {hitung }} 6,73>\mathrm{t}_{\text {tabel }}=1,66$ maka dapat disimpulkan $\mathrm{H}_{1}$ diterima artinya terdapat pengaruh yang signifikan terhadap keterampilan menulis teks prosedur antara siswa yang mendapat pembelajaran menggunakan metode karyawisata dengan siswa yang tidak menggunakan metode karyawisata. Saran bagi guru, diharapkan menggunakan metode karyawisata dalam keterampilan menulis laporan karena efektif dalam meningkatkan keterampilan menulis laporan siswa.

\section{E. DAFTAR PUSTAKA}

Afandi, Muhammad Idris dan Zulaeha, Ida. 2017. Efektifitas Buku Pengayaan Menulis Teks Hasil Observasi Bermuatan Multikultural Berbasis Proyek Baca Tulis untuk Peserta Didik SMP. Jurnal Seloka. Vol 6 No 2 PP 187-199

Mugianto, Ridhani, Ahmad, dan Arifin, Syaiful. 2017. Pengembangan Perencanan Pembelajaran Menulis Teks Laporan Hasil Observasi Model Pembelajaran Berbasis Proyek Siswa Kelas X SMA. Jurnal Ilmu Budaya Vol 1 No 4 PP 353-366 
Lingua Rima: Jurnal Pendidikan Bahasa dan Sastra Indonesia

Vol. 10 No. 2 Juli 2021

http://jurnal.umt.ac.id/index.php/lgrm

Putri, Diana dan R., Syahrul. 2019. Korelasi Keterampilan Membaca Pemahaman dan Keterampilan Menulis Teks Laporan Hasil Observasi Siswa Kelas VII SMP Negeri 4 Pariaman. Jurnal Pendidikan Bahasa dan Sastra Indonesia. Vol 8 No 1 PP 62-69

Sari, Yuliana, R., Syahrul, dan Rasyid, Yuliati 2018. Hubungan Antara Keterampilan Membaca Pemahaman dengan Keterampilan Menulis Teks Laporan Hasil Observasi Siswa Kelas X SMK Negeri 3 Padang. Jurnal Pendidikan Bahasa dan Sastra Indonesia. Vol 7 No 3 PP 46-453

Yulia, Wiwin. 2017. Peningkatan Keterampilan Menulis Teks Laporan Hasil Observasi dengan Menggunakan Metode Field Trip. Jurnal Diksatrasia. Vol 1 No 2 PP 349-357. 